Cornell Law Library

Scholarship@Cornell Law: A Digital Repository

Cornell Law Faculty Publications

Faculty Scholarship

$10-1-2007$

\title{
Cleaning House: Congressional Commissioners for Standards
}

Josh Chafetz

Cornell Law School, jc2284@cornell.edu

Follow this and additional works at: http://scholarship.law.cornell.edu/facpub

Part of the Ethics and Professional Responsibility Commons, and the Politics Commons

\section{Recommended Citation}

Chafetz, Josh, "Cleaning House: Congressional Commissioners for Standards" (2007). Cornell Law Faculty Publications. Paper 166. http://scholarship.law.cornell.edu/facpub/166

This Article is brought to you for free and open access by the Faculty Scholarship at Scholarship@Cornell Law: A Digital Repository. It has been accepted for inclusion in Cornell Law Faculty Publications by an authorized administrator of Scholarship@Cornell Law: A Digital Repository. For more information, please contact jmp8@cornell.edu. 


\section{THE YALE LAW JOURNAL}

\section{COMMENT}

\section{Cleaning House: Congressional Commissioners for Standards}

The past two years have seen a profusion of congressional scandals of all sorts, from official corruption (William Jefferson and Duke Cunningham, among others) to personal misconduct (Mark Foley comes to mind). Exit poll data suggest that these scandals played a significant role in the Democrats' victory in the 2006 midterm elections. ${ }^{1}$ Unsurprisingly, the new Democratic majority has made ethics reform a priority. ${ }^{2}$ Most significantly, both the House and the Senate have amended their rules to forbid the acceptance of gifts from lobbyists or firms that employ lobbyists. ${ }^{3}$ However, these stricter substantive rules will be largely meaningless without a stronger enforcement mechanism.

Who should be tasked with this enforcement role? For several reasons, the legislative branch itself is best suited for this responsibility. First, investigations of members by the Department of Justice and punishment of them in the courts raise serious questions under the Constitution's Speech or Debate Clause. ${ }^{4}$ The best reading of this Clause would protect meetings between

1. See, e.g., Jeff Zeleney \& Megan Thee, Exit Polls Show Independents, Citing War, Favored Democrats, N.Y. TIMES, Nov. 8, 2006, at P9 (finding that corruption and scandals were either "extremely important" or "very important" to seventy-four percent of voters in determining their votes for the House of Representatives).

2. See, e.g., David D. Kirkpatrick, Senate Passes Vast Overhaul in Ethics Rules, N.Y. TIMES, Jan. 19, 2007, at A1 (noting sweeping ethics reform proposals that have passed both the House and the Senate); Elizabeth Williamson, Draining the 'Swamp' Is Not So Easy: Skeptics Question Bite of Ethics Rules, WASH. POST, Aug. 7, 2007, at A11 (noting congressional passage of further ethics reforms).

3. S. 1, 110th Cong. $\$ \$ 108-109$ (2007) (amending Senate Rule XXXV); H.R. Res. 6, 11oth Cong. $\$ \$ 203-208$ (2007) (amending House Rules XXIII, XXV).

4. U.S. CONST. art. I, $\mathbb{S} 6, \mathrm{cl} .1$ ("[F] or any Speech or Debate in either House, [senators and representatives] shall not be questioned in any other Place."). I have discussed the Clause in significantly more detail in Josh ChafeTz, Democracy's PRIVILEGED FeW: Legislative 
members and their constituents, as such meetings are a vital component of the congressional function. ${ }^{5}$ Much alleged congressional wrongdoing, however, involves such interactions between members and their constituents (or other interested citizens). If the speech or debate privilege indeed extends to constituent communications, then it is not for another branch of government to distinguish "good" constituent communications ("You should vote for this bill because it's good policy, Senator.") from "bad" ones ("You should vote for this bill because there's something in it for you, Senator."). To allow the executive and judiciary to probe such distinctions would be to undercut the very point of this broad congressional privilege. ${ }^{6}$

But even if the courts reject Speech or Debate Clause challenges, ${ }^{7}$ it is less than ideal to leave the executive and judicial branches with the responsibility for policing the legislature. Doing so raises a more general separation-ofpowers concern: respect for a coequal branch of government should, at the very least, caution the executive and the judiciary to tread lightly when probing into the affairs of the legislature. In this vein, consider the thorny issues raised by the search of Representative William Jefferson's congressional office. ${ }^{8}$

Finally, public disgust with congressional corruption extends well beyond those comparatively few districts represented by corrupt members, ${ }^{9}$ which

Privilege and Democratic NORMS in the BRITISH AND AMERICAN CONSTITUTIONS 87-110 (2007). See also Josh Chafetz, Privileged, New Republic Online, May 31, 2006, http://www.tnr.com/doc.mhtml? $\mathrm{i}=$ wo60529\&s=chafetzo53106 (applying this analysis to the FBI's search of Representative William Jefferson's congressional office).

5. See Sam J. Ervin, Jr., The Gravel and Brewster Cases: An Assault on Congressional Independence, 59 VA. L. REV. 175, 184-88 (1973) (vigorously presenting a senator's perspective that constituent communications are vital legislative activity).

6. See Thomas Jefferson, Petition to Virginia House of Delegates, in 8 THE Works OF ThOMAS JEFFERSON 322, 325-26 (Paul Leicester Ford ed., 1904) ("FF]or the Judiciary to interpose in the legislative department between the constituent and his representative, ... to overawe the free correspondence which exists and ought to exist between them, ... to put the representative into jeopardy of criminal prosecution, of vexation, expense, and punishment before the Judiciary, if his communications, public or private, do not exactly square with their ideas of fact or right, or with their designs of wrong, is to put the legislative department under the feet of the Judiciary, is to leave us, indeed, the shadow, but to take away the substance of representation ....").

7. Indeed, the courts most likely would reject such challenges. See United States v. Brewster, 408 U.S. 501 (1972) (allowing a member of Congress to be tried for bribery). For criticism of Brewster, see CHAFETZ, supra note 4, at 106-07; and Ervin, supra note 5.

8. See, e.g., Akhil Reed Amar, Mr. Jefferson, Meet Mr. Jefferson, SLATE, May 26, 2006, http://www.slate.com/id/2142462 (suggesting that "even if William Jefferson and his congressional colleagues do not have a winning constitutional argument, the president and his men might do well to tread lightly" because of separation-of-powers concerns).

9. See supra note 1 . 
suggests that many voters consider Congress as an institution to be corrupt. A Congress that cleaned its own house(s), rather than relying on the other branches to police it, would go a long way toward repairing its reputation after all, self-restraint is generally taken as a sign of responsibility and trustworthiness. ${ }^{10}$ Surely, there is public benefit in restoring confidence in our democratic institutions.

Of course, for congressional self-regulation to be any improvement, it must be effective. Unfortunately, the congressional ethics committees have been part of the problem more often than they have been part of the solution. ${ }^{11}$ Outsiders are not allowed to bring complaints before the committees, and members are often unwilling to file complaints against their colleagues. ${ }^{12}$ Even normal political checks have broken down when it comes to the ethics committeeslike efficient duopolists, the two parties have simply colluded to avoid investigations. ${ }^{13}$ When committee members have violated this agreement, party leaders have punished them. ${ }^{14}$

But the failure of these committees should not lead us to give up on the concept of congressional self-regulation. Instead, this Comment proposes a new congressional oversight body, modeled on the British Parliamentary Commissioner for Standards.

10. See generally Josh Chafetz, Politician, Police Thyself, N.Y. TIMES, Dec. 2, 2006, at A15 (examining the history of Anglo-American legislative self-discipline and concluding that congressional leaders "should prove that they are serious about governing in a more responsible way by reinvigorating Congressional self-discipline").

11. See generally Joe Cantlupe, Bribery Case Shows House Panel Laxness, Critics Claim, SAN DIEGo UnION-TRIB., Dec. 1, 2005, at A1 (noting the inefficacy of the congressional ethics committees); Dierdre Shesgreen, Congress Split over Handling Ethics Inquiries, ST. LoUIS POST-DisPaTCH, Mar. 12, 2006, at B4 ("Watchdog groups have long criticized the House and Senate ethics committees as ineffective and toothless. That perception has only grown in the last year....").

12. See Cantlupe, supra note 11 ("Under House rules, an outside person or agency isn't allowed to make an ethics complaint. So the group [Citizens for Responsibility and Ethics in Washington] shopped around among members of Congress to see if someone was interested in filing a complaint against [Randy] Cunningham. No one was.").

13. See id. ("The [House] ethics committee has been in political paralysis for several years as congressional leaders have called a truce in investigating one another, critics say."); Shesgreen, supra note 11 ("The House [ethics] panel hasn't looked into a single case in more than a year. And while the Senate committee can't release any information about its current activities because of confidentiality rules, its last public action against a senator was in 2002.").

14. See Shesgreen, supra note 11 (noting that the committee and subcommittee chairmen who oversaw the 2004 admonishment of Tom DeLay were promptly removed from the ethics committee). 


\section{THE PARLIAMENTARY COMMISSIONER FOR STANDARDS}

In 1995, a committee, chaired by Lord Nolan and charged with recommending changes in the law aimed at restoring confidence in public officials, proposed creating a Parliamentary Commissioner for Standards. ${ }^{15}$ The House of Commons created the office that same year. ${ }^{16}$ The office has five key features. First, the Commissioner is not a member of the House of Commons, but she is an official of the House. Her position was created by a single-house resolution, not by statute, and she does not hold her office by virtue of a letter patent from the Crown. ${ }^{17}$ The British have long treated executive and judicial inquiry into alleged impropriety by members as a breach of parliamentary privilege, ${ }^{18}$ and, to this day, no member of Parliament has ever been convicted in the courts for bribery. ${ }^{19}$ Thus, any officer overseeing parliamentary ethics had to be an officer of the House.

Second, the Commissioner's office is structured to give her a good deal of independence and job security. Her term lasts for five years and is nonrenewable. She may be dismissed by resolution of the House only after the Committee on Standards and Privileges issues a report recommending her dismissal. ${ }^{20}$

Third, there is a regularized mechanism by which ethics complaints against members can be brought to the Commissioner's attention. ${ }^{21}$ Importantly, members of the general public, not just members of Parliament, can file complaints. $^{22}$

15. See 1 Committee on Standards in Public Life, First Report, 1995, Cm. 2850-I, at 40-45 [hereinafter NOLAN REPORT].

16. 251 H.C. JOUR. 469-70 (1995).

17. NOLAN REPORT, supra note 15, at 41-43; Diana Woodhouse, The Parliamentary Commissioner for Standards: Lessons from the 'Cash for Questions' Inquiry, 51 PARLIAMENTARY AFF. 51, 52 (1998).

18. Thus the British, unlike the Americans, accept the broad view of parliamentary privilege discussed above. See supra text accompanying notes 4-6; see also CHAFETZ, supra note 4 , at 9o, 199 (noting that members of Parliament cannot be tried in the ordinary courts for bribery and examining how the houses of Parliament themselves have disciplined members who have taken bribes); Dawn Oliver, The Committee on Standards in Public Life: Regulating the Conduct of Members of Parliament, 48 PARLIAMENTARY AfF. 590, 595 (1995) (noting that concerns of parliamentary privilege prevent external regulation of parliamentary ethics).

19. See Thomas Erskine May, Erskine May's Treatise on the Law, Pruileges, Proceedings AND USAGE OF ParLIament 134-35 (Sir William McKay ed., 23d ed. 2004).

20. Id. at 483 .

21. NOLAN REPORT, supra note 15 , at 43 ; ERSKINE MAY, supra note 19 , at $493-96$.

22. See Woodhouse, supra note 17 , at 51 . 
Fourth, when a complaint is filed, the Commissioner has the discretion to decide whether it merits investigation. If it does, she may issue subpoenas via the Committee on Standards and Privileges. ${ }^{23}$ Alternatively, she may reach a settlement with the Member. ${ }^{24}$ She may not, however, publish her findings without the Committee's permission. ${ }^{25}$

Finally, if the Commissioner finds additional investigation warranted, she passes her findings on to a subcommittee of the Committee on Standards and Privileges, which conducts further and more formal investigations, usually open to the public. ${ }^{26}$

\section{LESSONS FROM THE BRITISH MODEL}

The British model thus manages to keep enforcement of parliamentary ethics rules within the House, while simultaneously providing a relatively impartial enforcer. ${ }^{27}$ The model of the Parliamentary Commissioner should prove instructive to the houses of Congress in several ways. ${ }^{28}$

First, the Parliamentary Commissioner's fixed term assures a level of independence. Once appointed, she is difficult to remove-even more so because of the negative publicity that would accompany such an action. In contrast, it is very easy for the majority party in a house of Congress to reshuffle committee assignments in order to prevent zealous enforcers from serving on ethics committees. ${ }^{29}$ Moreover, the nonrenewability of the term means that the Commissioner has no incentive to try to please the parliamentary majority.

Second, the fact that anyone-whether a member of Parliament or notcan file a complaint with the Commissioner ensures that members cannot band together to prevent all investigations, as has happened with the congressional

23. NOLAN REPORT, supra note 15 , at $43-44$.

24. Id.

25. See Woodhouse, supra note 17 , at 54 .

26. NOLAN REPORT, supra note 15 , at 44-45.

27. See generally Peter Riddell, The Lords Lag Behind in Keeping Their House in Order, TIMES (London), July 17, 2007, at 6 (noting the success of the Parliamentary Commissioner in enforcing ethics in the House of Commons).

28. See generally ADRIAN VermeUle, MECHANISMS OF DEMOCRACY: INSTITUTIONAL DESIGN WRIT SMALL 20 (2007) (noting, in a different context, that ${ }^{\circ}[t]$ he fact that Parliament has set up a similar body ... is a first step towards dispelling concerns about [the] feasibility [of a proposed new congressional body]").

29. See supra note 14 and accompanying text. 
ethics committees. $^{30}$ Had nonmembers been permitted to file ethics complaints, perhaps Representative Mark Foley's improper contact with teenage House pages would have come to light earlier. ${ }^{31}$

Of course, if anyone were allowed to file ethics complaints under the current American system, the ethics committees - whose members have many other demands on their time-would likely find themselves overburdened. Allowing members of the public to file complaints means that wrongdoing is more likely to be brought to light, but it also requires an official whose fulltime job consists of sorting through these complaints. ${ }^{32}$ Wading through such complaints is a large part of the British Commissioner's job.

Finally, the fact that the parliamentary Committee, rather than the Commissioner, is ultimately responsible for punishing misbehaving members ensures that the Commissioner does not act as both prosecutor and judge. Moreover, the punishment of an elected representative is an issue of some moment, and thus it is consistent with democratic principles that the ultimate arbiters of such punishment be other elected officials. The publicity that inevitably surrounds the Commissioner's report serves to ensure that the representatives perform this function with the public looking over their shoulders.

However, this also points to several ways in which the British institutional design could be improved for importation into the United States. The Parliamentary Commissioner may not publish her own findings, ${ }^{33}$ thus raising the possibility that the Committee on Standards and Privileges will simply choose to ignore them. In contrast, allowing the Commissioner to publish her reports would put intense public pressure on the Committee to act on them, and a Committee determined not to act would, at the very least, have to provide good reasons for failing to do so.

Similarly, the Commissioner has neither the power to subpoena documents on her own, nor the power to take testimony under oath. She must appeal to the Committee to exercise those powers on her behalf. ${ }^{34}$ This, again, might

30. See supra notes $12-13$ and accompanying text.

31. See Carl Hulse \& Raymond Hernandez, Top G.O.P. Aides Knew in Late 'o5 of E-mail to Page, N.Y. TIMES, Oct. 1, 2006, at A1.

32. Cf. Parliamentary Commissioner for StANDARDS, ANNUAl RePORT, 2005-6, H.C. 1480, at 13 , available at http://www.publications.parliament.uk/pa/cm200506/cmselect/cmstand/ 1480/1480.pdf (noting that, of the 129 complaints filed against specific members between April 2005 and March 2006, 106 were not pursued, primarily because they raised issues outside of the scope of the Commissioner's office).

33. See Woodhouse, supra note 17 , at 54 .

34. Id. at 52-53. 
allow a Committee majority to stifle an investigation. Publicity is undoubtedly a partial answer to this problem as well-a Commissioner willing to publicly denounce the parliamentary Committee for stonewalling her investigation would likely get what she wants - but giving the Commissioner subpoena and oath-administering powers is a fuller response. ${ }^{35}$

Finally, the mode of appointment of the Commissioner could be improved. As the Commissioner must be seen to transcend partisan politics, a supermajority appointment procedure is warranted. At the Philadelphia Convention, James Madison told his colleagues that the expulsion of a member of Congress "was too important to be exercised by a bare majority of a quorum: and in emergencies of faction might be dangerously abused." Madison proposed a two-thirds supermajority requirement, ${ }^{36}$ which the Convention adopted. ${ }^{37}$ A similar requirement for the appointment of the official tasked with conducting the investigations that might lead to such punishments seems similarly justified.

\section{CONGRESSIONAL COMMISSIONERS FOR STANDARDS}

To address the inadequacies of the current ethics committees, Congress should create a Commissioner for Standards for each house of Congress, structured to improve upon the British model. (It is desirable to have a separate Commissioner for each house, as a single Commissioner for both houses would raise unnecessary procedural complications..$^{38}$ ) Each house's Commissioner

35. See id. at 59 (proposing this reform in Britain).

36. 2 THE RECORDS OF the Federal CONVENTION OF 1787, at 254 (Max Farrand ed., rev. ed. 1966).

37. See U.S. ConST. art. I, $\$ 5$, cl. 2 ("Each House may ... with the concurrence of two-thirds, expel a member.").

38. The creation of a single Commissioner for both houses would presumably require a statute, rather than an internal house rule created by resolution. There are serious questions about the houses' ability to create rules by legislation. See Aaron-Andrew P. Bruhl, If the Judicial Confirmation Process Is Broken, Can a Statute Fix It? 85 NEB. L. REV. 960, 1007-10 (2007) (arguing that a statute purporting to govern the internal rules of a house of Congress could nor be legally binding). If, as Bruhl suggests, a statute purporting to determine house rules could be overridden by a single-house resolution, then the House and Senate could issue mutually inconsistent, but equally binding, instructions to the Commissioner. The obvious solution is for each house to have its own Commissioner. However, nothing should prevent the two offices from being vested in the same person, who would follow House rules when investigating representatives and Senate rules when investigating senators, thus avoiding the problem of inconsistent rules. 
would be appointed for a fixed, nonrenewable term. ${ }^{39}$ The appointment would come via a resolution of the house, passed with a two-thirds supermajority. Each Commissioner would be required to create a regular procedure by which anyone-whether a member of Congress or not-could bring an ethics complaint to her attention.

A Commissioner would be obligated, first, to determine whether a filed complaint actually asserts a violation of the house's ethics rules. ${ }^{4^{\circ}}$ If it does, the Commissioner should proceed to a preliminary investigation, during the course of which she would have the power to issue subpoenas and compel testimony under oath. At the conclusion of this preliminary investigation, she may dismiss the complaint, reach a settlement with the accused member, or conclude that further investigation is warranted. In any case, in contrast to the British model, she would be required to publish her findings. ${ }^{41}$ If further investigation is warranted, it would be conducted by the Ethics Committeeand that Committee would have ultimate responsibility for determining the proper punishment. Given the Commissioner's published report detailing the need for further investigation, the Ethics Committee likely would encounter significant political difficulty if it refused to take up the matter.

\section{CONCLUSION}

The institutional design laid out above would leave congressional ethics enforcement within the houses of Congress, thus avoiding the problems with external enforcement laid out in Part I, while simultaneously minimizing the possibility that the Commissioners will be "captured" by those they are meant to regulate. ${ }^{42}$ The independence of the office, the supermajority (and therefore

39. For the House Commissioner, the term could not exceed two years, as the procedural rules of one House of Representatives cannot bind a future House. See WM. HOLMES BROWN \& Charles W. Johnson, House Practice: A Guide to the Rules, Precedents, and Procedures of THE HoUSE 162 (2003).

40. This might be thought of as the equivalent of a determination of whether the complaint states a claim upon which relief can be granted by the Commissioner. Cf. FED. R. CIV. P. 12(b)(6).

41. She should, however, be allowed to redact portions of her findings if publishing them would violate the privacy of third parties or would otherwise result in the release of sensitive information.

42. Regulatory capture theory suggests that regulators tend to act at the behest of interest groups seeking to maximize their own benefits, rather than in the public interest. See Richard A. Posner, Theories of Economic Regulation, 5 BELL J. ECON. \& MGMT. SCI. 335, 335-36 (1974) ("Espoused by an. odd mixture of welfare state liberals, muckrakers, Marxists, and free-market economists, this theory holds that regulation is supplied in response to the 
typically bipartisan) nature of the appointment process, and the provisions encouraging publicity all lessen the possibility of capture. The Federal Election Commission provides an instructive contrast. A 2000 New York City Bar commission report suggested that the FEC had been captured, finding that

[m]any of the problems with the FEC are built into its basic structure, including the even number of commissioners, the lack of a long-term chair, and the partisan appointments process, as well as congressionally imposed restrictions on the FEC's investigatory and enforcement powers. As a result, the FEC is frequently incapable of taking effective action against the major parties or their candidates. ${ }^{43}$

The structure of the office proposed in this Comment avoids all of these difficulties. It is vested in a single person in each house; the appointment is for a significant period of time; and it possesses the power to both investigate and publicize alleged wrongdoing. Although it does not have independent enforcement power, its publicity power will put substantial pressure on the committees charged with enforcement.

Ultimately, this office would serve to regularize and strengthen the enforcement of congressional ethics, while keeping final responsibility within Congress itself. The result would likely be an increase in public trust in the most representative branch of our government. That, surely, is a worthwhile innovation.

JOSH CHAFETZ

demands of interest groups struggling among themselves to maximize the incomes of their members."). Where, as in the case of ethics regulation, the interests of one group (the legislators) is concentrated, and the countervailing interest (the public interest) is diffuse, capture theory suggests that the regulator will act at the legislators' behest. See Robert E. Thomas, Vanquishing Copyright Pirates and Patent Trolls: The Divergent Evolution of Copyright and Patent Laws, 43 AM. Bus. L.J. 689, 692 n.13 (2006) (suggesting that "a one-to-one correspondence between regulatory action and the interests of large interest groups" is evidence of regulatory capture).

43. Comm'n on Campaign Fin. Reform, Ass'n of the Bar of the City of N.Y., Dollars and Democracy: A Blueprint for Campaign Finance Reform-Introduction and Summary, 55 RECORD 645, 657 (2000). 